\title{
English Songs as Supplementary Materials in the Teaching of Paragraph Writing
}

\author{
Emeteria Leonila A. Perez \\ Polytechnic University of the Philippines, Philippines
}

\begin{abstract}
This study evaluates the effectiveness of English songs as supplementary materials in the teaching of paragraph writing to college students. It also intends to evaluate the performance of the experimental and control groups in the pretests and posttests and the significant difference in the performance of two groups in writing paragraphs by description, character sketch, and analogy. The value of songs in motivating students to learn English and enhancing learner involvement is widely acknowledged by teachers. Moreover, teachers and students alike find singing songs entertaining and relaxing. Songs offer a change from the routine procedures in the classroom. They are invaluable tools to develop students' language abilities in reading and writing. Finally, learning English through songs also provides a non-threatening atmosphere for students.
\end{abstract}

Keywords: songs, supplementary materials, description, character sketch, analogy

\section{Introduction}

English as a branch of knowledge has many facets. It encompasses an array of disciplines that also include the four macro language skills, one of which is writing. The most common problem that confronts teachers of a writing class does not lie so much on what to ask students to write about; the difficulty is more on how to motivate the students to write interesting and effective materials (Ikeguchi, 1997). The value of songs in motivating students to learn English and enhancing learner involvement is widely acknowledged by teachers. Moreover, teachers and students alike find singing songs entertaining and relaxing. Songs offer a change from the routine procedures in the classroom. They are invaluable tools to develop students' language abilities in reading and writing. Learning English through songs also provides a non-threatening atmosphere for students (Lo \& Fai Li, 1998).

\section{Objectives}

The study aimed to evaluate the effectiveness of English songs as supplementary materials in the teaching of paragraph writing to college students. Specifically, the study intended to answer the following questions:

(1) What is the performance of the experimental group in the pretest and the posttest?

(2) What is the performance of the control group in the pretest and the posttest?

Emeteria Leonila A. Perez, Asst. Prof IV, DEM (candidate), Master of Arts in Language Teaching (MALT), Department of English Foreign Languages and Linguistics, College of Arts and Letters, Polytechnic University of the Philippines. 
(3) Is there a significant difference in the performance of the two groups?

(4) What are the implications of the findings on the effectiveness of using songs in teaching paragraph writing?

\section{Conceptual Framework}

The input consists of the experimental group that was given a pretest and a posttest. The control group was also given the same set of tests. In the process, the results of the tests are analyzed and interpreted. In the output, the implications of the findings on the improvement of the teaching of paragraph writing are discussed.

\section{Research Methodology}

\section{Population or Sampling Design}

Two regular freshman classes from the Polytechnic University of the Philippines were used as subjects of the study. The students in these two classes have almost the same mean average in their previous level. The students were evaluated through the use of pretest and posttest. The written output of students was likewise evaluated using the set of criteria made by the researcher. The choice of first year students was significant because they already had knowledge of the methods of paragraph development at this stage in their academic life.

\section{Measurement and Data Collection Design}

This is a quasi-experimental research using two complete classes. It explored the possibility of utilizing songs as supplementary materials in teaching paragraph writing. The researcher went through the following steps:

(1) Collection of English songs. The researcher collected songs from the Ultimate 101 Songbook Volume 2 and Ultimate Songbook Silver Edition. These compilations contain songs from the 1950s to the 1990s, from groups as diverse as the Beatles, The Carpenters, and Air Supply, from singers both local and international, to genres as varied as folk, ballad, jazz, and rock.

(2) Identification and selection of songs that can be used as supplementary materials in teaching English. The researcher identified and selected the songs based on this set of criteria: (a) suitability of the songs to the methods of paragraph development; (b) moral values that could be derived from the songs; (c) message of the songs; and (d) popularity of the songs.

More than 20 English songs were collected for the three methods of paragraph development (description, character sketch, and analogy) but only nine songs (three songs for each method) were chosen by the researcher for use with the experimental group.

(3) Pre-writing activity. The researcher motivated the students (both in the control and experimental groups) on the lessons to be discussed.

(4) Writing activity (Pretest). Students both in the control and experimental group were asked to write a short paragraph consisting of 100-150 words using the method discussed in the motivation part of the lesson. They were restricted to a time limit of 20 minutes to finish their work.

(5) Lesson proper. (a) Control group. The researcher/teacher discussed the lessons thoroughly but without the adoption of songs to illustrate each of the methods of paragraph development that they were to use in their compositions. 
(b) Experimental group. The researcher/teacher discussed the lessons thoroughly but this time integrating the songs in the lessons on paragraph development. After the explanation of the lessons, the teacher played the songs on CD, the lyrics of which were provided to the students. They were allowed to sing along while songs were played in class. After the listening/singing along session, the teacher asked a few questions regarding the songs and their relevance to the paragraph writing lesson.

(6) Post-writing activity (Posttest). Both the control and experimental groups were asked to rewrite the paragraphs they wrote during the pretest. These served as their final draft. They were again restricted to a time limit of 20 minutes.

(7) Assessments of tests. Using the rubrics and scale adopted by the researcher from the internet and other theses, the pretests and posttests were evaluated.

\section{Analytical Design}

The quasi-experimental method of research was used in the study. It is a research design which has some but not all of the characteristics of a true experiment. Since the study is concerned with the effectiveness of English songs as supplementary materials in the teaching of paragraph writing, the experimental method is the most appropriate method to use.

\section{Results}

\section{Experimental Group}

In the pretest on paragraph by description, out of 44 respondents six or $13.6 \%$ obtained Close-to-Standard scores and almost $67 \%$ of the work of the respondents was Acceptable.

In the posttest on paragraph by description, 64\% got scores of Standard while $13.6 \%$ acquired Close-to-Standard scores.

In the pretest on paragraph ay character sketch, around $11 \%$ of the respondents got scores equivalent to Close-to-Standard and 75\% obtained Acceptable and 5\% acquired Non-standard scores.

In the posttest on paragraph by character sketch, $68.2 \%$ acquired scores of Standard and $20.5 \%$ acquired Close-to-Standard scores.

In the pretest on paragraph by analogy, 4.5\% achieved Standard ratings in their scores, and $6.8 \%$ Close-to-Standard. Some students acquired 81.8 Acceptable score.

In the posttest on paragraph by analogy, $66 \%$ of the students got a score of Standard; and $18.2 \%$ acquired Close-to-Standard; $2.3 \%$ obtained Acceptable scores in the examination.

\section{Control Group}

In the pretest on paragraph by description, $83.7 \%$ acquired a score of Acceptable and $12.2 \%$ Close-to-Standard.

In the posttest score on paragraph by description, $14.3 \%$ got a score of Standard, $15.15 \%$ acquired Close-to-Standard, and 22.4\% obtained Acceptable score in the examination.

In the pretest on paragraph by character sketch, $2.0 \%$ obtained a Close-to-Standard score, $63.3 \%$ gained Acceptable, and $6.1 \%$ earned Non-standard score. 
In the posttest on paragraph by character sketch, 38.8\% achieved Standard in their scores, $32.7 \%$ Close-to-Standard, and 2.0\% Acceptable.

In the pretest on paragraph by analogy, $2.0 \%$ got a score of Close to Standard, $85.7 \%$ Acceptable, and $12.2 \%$ Non-standard.

In the posttest on paragraph by analogy, $34.7 \%$ got a Standard score while $65.3 \%$ acquired Close-to-Standard.

\section{Conclusions and Discussions}

The study revealed the following:

(1) The experimental group's good performance in the pretest and posttest was an indication that the intervention of songs in the lessons was effective.

(2) The control group did not perform well in the pretest and posttest suggesting that students did not produce well-crafted output when the teacher used traditional methods of teaching that had lost their novelty and appeal.

(3) There was a significant difference in the performance of the two groups. The experimental group exhibited more interest than the control group in writing as the findings of the study reflected.

(4) Students produced better written output when the lesson uses songs that they were familiar with, those whose message they could easily understand and those whose melody and tempo they found appealing.

(5) Songs are generally commendable as instructional materials in paragraph writing, specifically in teaching paragraph by description and paragraph by analogy.

\section{Suggestions}

In the light of the results and conclusions drawn from the study, the researcher recommends the following:

(1) Teachers handling paragraph writing subjects can use English songs as supplementary materials in their lessons especially in paragraph by description and paragraph by analogy.

(2) Teachers who will incorporate songs in their lessons should choose the more modern/recent ones whose message can be easily understood by the young and those with a melody and beat students can sing/hum with or even dance to.

(3) Teachers should have a wide repertoire of songs to be utilized in the teaching of paragraph writing.

(4) Future researchers can conduct another study, this time using the latest songs from famous contemporary artists.

(5) Future researchers can make other studies focus on the songs images, figures of speech, vocabulary, etc.

(6) Curriculum experts should consider the use of English songs not only in the teaching of paragraph writing in English but also of other subjects such as Creative Writing and the like.

\section{References}

Ikeguchi, C. B. (1997). Teaching integrated writing skills. The Internet TESL Journal, 3(3).

Kavaliauskiene, G. (2005). Music in the ESP Classroom. ESP World.

Lo, R., \& Fai Li, H. S. (1998). Songs enhance learner involvement. English Teaching Forum, 36(3), 8-11.

Mc Govern, A. M. (2000). Working in harmony: Some effects of music in the classroom. ERIC Digest.

Poupure, J. (2007). Using arts to better the art of teaching. Harvard University Gazette On-Line.

Schoepp, K. (2001). Reasons for using songs in the ESL/EFL classroom. The Internet TESL Journal, 7(2), 1-4. 